УДК 246.6.001.32(045)
М. С. Мельничук,
кандидат філософських наук, доцент
(Національний університет водного господарства та природокористування, м. Рівне)
m.s.melnuchykenuwm. edu.ua
ORCID: 0000-0002-4299-968X

\title{
ЕКЗЕГЕЗА ФАНТАЗІЇ В РАКУРСІ ВИТОКІВ РЕЛІГІЙНОГО МИСТЕЦТВА
}

\begin{abstract}
Автор статті досліджує місце та роль фантазії у процесі виникнення та функціонування релігійного мистеитва. У даній науковій розвідиі демаркуються поняття релігійної та художньої фантазії. Аналізується дане явище $і$ як результат образного узагальненого мислення, $і$ як внутрішня духовна необхідність усвідомлення ірраціонального. Фантазія автором представлена як неодмінний елемент релігійного мистецтва, який відображає форми існування, пізнання й діяльності людини.
\end{abstract}

Ключові слова: фантазія, мистецтво, релігія, релігійне мистецтво, емоиії, катарсис.

Постановка проблеми дослідження. Духовна ситуація на тлі реалій України сьогодення характеризується новітніми тенденціями розгляду такого явища, як релігійне мистецтво. Значну роль у процесі зародження та розвитку релігійного мистецтва відігравала людська фантазія. Але місце та роль ії мали полігранний характер. Зі сторони естетичних почуттів, зі всією силою та їх розмаїттям інтересів спрямованих на реальний об'єкт, виступало специфічною "практично-духовною" формою його засвоєння. Релігійні ж почуття завжди спрямовані на ілюзорні, не існуючі реально об'єкти.

Кожне покоління звертається до минулого, визначаючи ставлення до нього уже з висоти свого досвіду, досягнутого рівня розуміння історії, з висоти своїх завдань. Релігія - одна із ланок духовної еволюції людства, з якою пов'язаний великий етап історії суспільства. Вона виникла й існувала як історична й соціально зумовлена форма усвідомлення людьми навколишньої дійсності й самих себе. I ця наукова об’єктивність в оцінці релігії підкреслюється й витримується упродовж усього дослідження. Це відповідно позначається й на оцінці мистецтва, що його релігія слушно обрала для поглиблення свого впливу на людей, котрі в результаті виховання або інших об'єктивних чи суб'єктивних чинників стали послідовниками тієї чи іншої конфесії.

Актуальність дослідження. Посилення значущості релігійно-духовної складової в житті сучасної України, що акумулювалося 3 початком зародження оновленої національної свідомості, саме по собі актуалізує низку проблем, які вимагають переосмислення, переоцінки чи навіть нової їхньої оцінки. До цих проблем відноситься й взаємодія релігійного культу та мистецтва, яка здавна виступає важливим засобом впливу на духовне життя релігійно віруючих людей. Йдеться наразі про сакральне мистецтво, точніше, про релігійне мистецтво. Для людини глибоко віруючої, не залежно до конфесійної приналежності, характерна слаборозвинута здатність перенаправляти чуттєві, образні враження на зовсім інший, навіть протилежний рівень жорстко логічного аналізу, на рівень умовиводів. Релігійна людина, як правило, переводить їх одразу у сферу принципів й уявлень, що склалися на основі віри. Саме тому в мистецтві, органічно пов'язаному з релігійним обрядом, всіляко, так би мовити, зашорюються елементи художньої фантазії. Суть релігійного канону в ракурсі мистецтва полягає в тому, що він емоції та невиразні реакції відразу трансформує на рівень жорстких, твердих релігійних уявлень, оминаючи творчу фантазію. Однак мистецтво завжди долало ці рамки догматики, й навіть у межах канонічних правил по-справжньому талановитий митець створював непересічні твори, народжені на основі єдності його творчої фантазії і знання про світ. Науковий інтерес до проблеми фантазії як явища, що стояло біля витоків релігійного мистецтва відображався у працях Р. Ото, М. Еліаде, Л. Левчук, Д. Писарєва, С. Яковлєва та багатьох інших релігієзнавців, філософів та мистецтвознавців.

Виклад основного матеріалу. Відображення дійсності в гармонійній єдності мистецтва і релігією, в ракурсі образного характеру зумовлює дві особливості, що зближують ці дві форми суспільної свідомості. Перша з цих особливостей - це велика роль фантазії у творенні як художніх, так і релігійних образів; і друга - шлях месседжу релігійного мистецтва до свідомості й розуму людини йде передусім через її серце та почуттєві здібності. Саме це було спільним знаменником релігії й мистецтва.

Фантазія виступає важливим інструментом творчого осмислення людиною матеріалу відображуваної реальності. Без фантазії неможливе абстрагування думки від конкретних даних, отримуваних людиною із зовнішнього світу, неможливе узагальнення цих даних, формування образів, понять чи категорій. Однак характер, масштаби й межі застосування фантазії при відображенні суспільного буття різними формами суспільної свідомості надто різноманітні. До фантазії неминуче вдаються науковці у процесі проникнення в реальну дійсність - при створенні моделі клітини, атому і т. ін. Але в науці фантазія зобов’язана бути жорстко підпорядкованою досвіду, фактам. Порушуючи цю вимогу, вчений стає на хиткий шлях безпідставного фантазування, який неминуче відведе його від істини. Д. Писарєв писав про дві мрії (фантазії). Існує мрія, яка збуджує в людині іï активність, веде ії вперед - до досягнення реальних 
цілей, мобілізує іiі чуття і волю. І є фантазія (мрія) іншого гатунку, яка розслаблює людину, відводить убік від реальної дійсності [1: 147-149]. Отже, фантазія відіграє надзвичайно велику роль як у сфері мистецтва, так і релігії. 3. Фройд вважав, що сутність мистецького твору становить фантазія. Завдання митця полягає в тому, щоб за допомогою фантазії створити "штучний світ", "сон наяву", "...побудувати надхмарний замок" [2: 132]. Передусім мистецтво як результат художньої діяльності неможливе без фантазії, без уяви. Будь-який твір мистецтва (навіть первісне образотворче мистецтво, первісна скульптура, пісня) - це не просте, "фотографічне" чи дзеркальне, відтворення реальності. В усі часи художник ніби переплавляє силою своєї уяви життєві враження, спостереження й образи. Звичайно, мистецтво відображає життя, але відображає його через лінзу світовідчуття й світогляду художника, який реалізує мистецький задум. I в цьому своєрідному баченні світу художником - один із виявів ролі фантазії, ролі творчої уяви у мистецтві. Й це стосується усіх часів, відколи людина заявила про свої творчі задатки і почала збагачувати духовний світ своїх сучасників і майбутніх поколінь.

Фантазія для мистецтва, тим паче мистецтва релігійного змісту є тим же, чим виразні рухи для мови. Діяльність фантазіі є першоджерелом будь-яких релігійних уявлень і почуттів. Ті самі уявлення, які створилися під впливом умов спільності життя, звичайно, носять характер, властивий творам фантазії. У міфах народна фантазія зазнає переживання дійсності; в релігії вона зі змісту цих переживань створює свої уявлення про сутність і мету людського існування, а в мистецтві вона дає цьому змісту свідомості конкретний образ, в залежності від зовнішніх умов життя і внутрішніх умов міці та волі.

Фантазія не може служити зовнішньою, легко впізнаваною ознакою. Вона видається чимось таким, що живе і діє у глибинах свідомості і (це можна припустити заздалегідь) є комплекс різних функцій; комплекс, який представляє найбільші труднощі не тільки аналізу, який прагне розкласти його на окремі фактори і визначити їх взаємодію, але і безпосереднього спостереження. Майже немає можливості відшукати ті нитки, з яких виткані уявлення фантазії, розплутати вузли, в які ці нитки сплітаються, знову розплітаються i, нарешті, в різний спосіб з'єднуються з іншими уявленнями, або самі з собою. Тому не дивно, що багато хто, незважаючи на логічні міркування задовольняються тим, що вважають діяльність фантазії першоджерелом мистецтва.

Безсумнівно, що мистецько-творче джерело і міфологічні уявлення, що становлять найважливіші елементи первісного змісту релігійного мистецтва $є$ тими джерелами, 3 яких ми можемо почерпнути найбільш багаті знання про суть фантазії в їі природній і загальнолюдській закономірності. Аналіз суті фантазії становить завдання як релігієзнавчої сторони мистецтвознавства, так і експериментальної психології, котра своїми методами пов'язана з індивідуальною свідомістю.

У релігійно-естетичній фантазії в процесі ставлення до об'єкта відображення домінує невиразне його передчуття. Саме тому гносеологія майже всіх історичних типів релігій орієнтувала і орієнтує релігійну людину й художника на те, що художній твір не є образ, який відображає істотне в реальному об'єкті, а всього лише нагадування про досконале, сакральне, ідеальне начало. В цій ідеї схоплений один із реальних моментів відображення дійсності людською свідомістю. Справді, емоція, як психофізіологічний момент відображення, безпосередньо не пов’язана 3 раціональною оцінкою об‘єкта. Тому через певну систему впливу на свідомість людини процес пізнання можна зупинити на стадії неясного, туманного відображення, яке не розкриває причинно-наслідкових зв'язків, й перевести його на наступну сходинку - висновків й узагальнень, на рівень не лише світовідчуття, але й світогляду. Порушується діалектична взаємодія чуттєвого і раціонального в процесі пізнання, в результаті чого досягається пізнання не об'єкта, а лише невиразне, зашорене його відображення. Через таку систему художньо-образних вирішень і естетичного впливу на людину релігії зміцнюють цей механізм як стійкий соціально-психологічний принцип поведінки віруючої людини [3].

Релігійна фантазія не просто створює вигадані, ілюзорні образи й уявлення - вона обов'язково включає віру в реальність цих фантастичних образів. Поза вірою в реальність надприродних образів сама релігія неможлива. При цьому варто враховувати, що релігійна людина вірить не лише в реальність надприродних істот, але і в те, що надприродні істоти здатні вплинути на їі життя, долю в реальному чи в потойбічному світі. Тому людина, в свою чергу, намагається вплинути на надприродне за допомогою особливих дій, які спочатку мали магічний характер, а згодом виявилися спрямованими на те, щоб умилостивити Бога, вимолити в нього порятунок від страждань та нестатків. На цій основі виникає релігійний культ як система особливих дій, які, на переконання віруючих, можуть і повинні вплинути на надприродне. Тобто, релігійна фантазія не лише видає свої творіння за реальність, але й передбачає обов'язкове культове поклоніння цим творінням. Культові дії чи й просто споглядання культового об'єкта, наприклад ікони, викликають у віруючої людини релігійні почуття, які здатні призвести до релігійного катарсису. Це особливий психологічний стан, який виникає у людини внаслідок глибокої молитви, богослужбових дій чи від споглядання художньо-релігійного твору. Полягає він у глибокому внутрішньому полегшенні, умиротворенні, самозаспокоєнні. По суті, релігійний катарсис є антитезою релігійного страху, який Р. Ото називає "нумінозним досвідом", в процесі набуття якого "...людина відчуває власну нікчемність..., 
урівноважується або повністю знімається" [4: 7]. Катарсис є яскравим проявом втішально-компенсаторної функції релігії, яку вона виконує в суспільстві.

Нічого подібного немає в художній фантазії і творчості. Але в процесі історичного розвитку нерідко відбувається переміщення одних і тих же образів і міфів із сфери релігії у сферу мистецтва. Так, наприклад, давньогрецькі міфи свого часу були важливим елементом релігії давніх еллінів, а згодом перетворилися в художні твори, популярність яких збереглася до наших днів. У гносеологічному аспекті процес взаємовідносин художньої й релігійної фантазій особливо яскраво демонструє їхню емоційну спільність і суперечливість в кінцевих гносеологічних цілях їхній художньо-естетичній антитезі. У мистецтві художній образ, як результат творчої фантазії, $є$ результатом "подолання" загадкового, непевного інтуїтивного рефлектування, що перетворює імпульсивні емоції в емоційно-раціональну цілісність. До того ж сам процес творення художнього образу передбачає органічне вплетення раціонального в естетичне ставлення художника до об'єкта своєї творчості. Це стає домінантою в процесі художнього ставлення до світу, тому що естетичні емоції - це "розумні емоції", які дозволяють художникові постійно включати себе в процес пошуку істотних ознак зображуваного об'єкта. Ці почуття проходять крізь горнило розуму, не втрачаючи при цьому своєї безпосередності, що й надає художньому образові зачарування, духовної глибини i зворушливості.

Не менш важливою закономірністю художньої фантазії і творчості виступає образна узагальненість мислення. Фантазія художника пов'язана 3 тим, що спрямована на творення ним художнього образу. Виявлення істотних сторін дійсності неможливе лише на рівні емоційних реакцій, воно вимагає глибокого раціонального осмислення. Саме тому фантазія художника несе раціональні рівні відображення світу задум, ідею, сюжет, фабулу. Раціоналістична зумовленість фантазії суб’єкта художньої творчості особливо виразно проступає в ії соціальній детермінованості, в наявності в ній певного світогляду, який є не лише світорозумінням, але й концепцією. Таким чином, онтологічна структура фантазії суб'єкта художньої творчості включає соціально-емоційне ставлення до світу. Перевага ж у ній емоційного елемента $\epsilon$ необхідною умовою творення художнього образу, пройнятого не лише соціальною ідеєю, не лише раціоналістичною глибиною, а й особистісним ставленням до світу, яке повинно бути реалізованим у художньому творі.

Висновки та перспективи подальших досліджень. Виникнення і розвиток релігійних уявлень неможливі без людської фантазії. Вже у найпростіших (і найдавніших) формах релігійних вірувань, наприклад у магії, чітко помітна роль фантазії. Здійснюючи магічні дії, первісна людина пов'язує їх у своїй фантазії з певним, бажаним для неї результатом. Згодом, у процесі подальшого історичного розвитку релігії, люди починають створювати фантастичні образи надприродних істот, що наділені свідомістю й волею - духів, богів. Головною ознакою, визначальним принципом релігійного відображення є віра в надприродне. Віруючі уявляють надприродних істот як реально існуючих, але ж насправді вони створені фантазією людей й існують як "справжні" лише в головах віруючих.

На противагу науці, де фантазія чітко обмежена рамками доцільності дослідження й підпорядкована йому, в мистецтві та релігії фантазія знаходить майже безмежні можливості для свого застосування й вияву. На перший погляд, відбувається зближення цих форм суспільної свідомості. Адже фантазію (творчу уяву художника) не обмежує ні простір, ні час. Письменник, живописець, сценарист, кінорежисер можуть легко "перенестись" із нинішнього дня на століття вперед чи назад. Можуть примусити нас "покинути" не тільки Землю чи межі Сонячної системи, але й нашу Галактику. "Допомагають" долати земне тяжіння, "озброюють" людину технічною могутністю, про яку вона не насмілюється навіть мріяти.

Подібним чином релігійна фантазія також утворює цілі неіснуючі світи, уявні сфери буття, протиставляючи їх реальному світові і намагаючись спростувати наукову картину світу. Релігійна фантазія населяє віртуальну дійсність надприродними істотами, приписує реальним предметам i явищам надприродні властивості і зв'язки, наділяє свої "образи" безмежною владою над природою й людиною, розглядає світ як результат Божого творіння та як сферу вияву божественної волі. І як результат, це втілюється у вічні, божественні шедеври світового релігійного мистецтва, що здатні спрямовувати людину до вічного, доброго, світлого.

\section{СПИСОК ВИКОРИСТАНИХ ДЖЕРЕЛ ТА ЛІТЕРАТУРИ}

1. Писарев Д. И. Сочинения : в 4 т. / Д. И. Писарев. - М. : Гослитиздат, 1956. - Т. 3 : Статьи, 1865-1868. $497 \mathrm{c.}$

2. Левчук Л. Т. Психоаналіз : історія, теорія, мистецька практика : [навч. посіб. для студентів гуманіт. спец. вищ. навч. закладів] / Л. Т. Левчук. - К. : Либідь, 2002. - 253 с.

3. Яковлев Е. Г. Эстетическое сознание, искусство и религия / Е. Г. Яковлев. - М. : Искусство, 1969. - 175 с.

4. Еліаде М. Священне i мирське. Міфи, сновидіння і містерії. Мефістофель i андрогін. Окультизм, ворожбитство та культурні уподобання / М. Еліаде. - К. : Вид-во Соломії Павличко "Основи", 2001. - 591 с. 


\section{REFERENCES (TRANSLATED \& TRANSLITERATED)}

1. Pisarev D. I. Sochineniia : v 4 t. [Writings] / D. I. Pisarev. - M. : Goslitizdat, 1956. - T. 3: Statti, 1865-1868. $497 \mathrm{~s}$.

2. Levchuk L. T. Psikhoanaliz : istoriia, teoriia, mistets'ka praktika [Psychoanalysis : History, Theory, Artistic Practice] : [navch. posib. dlia studentiv gumanit. spets. vishcha. navch. zakladiv] / L. T. Levchuk. - K. : Libid', 2002. $-253 \mathrm{~s}$.

3. Yakovlev Ye. G. Esteticheskoie soznaniie, iskusstvo i religiya [Aesthetic Consciousness, Art and Religion] / Y .G. Yakovlev. - M. : Iskusstvo, 1969. - 175 s.

4. Yeliade M. Svyashchenne i mirs'ke. Mifi, snovidinnia i misterii. Mefistofel' i androgin. Okul'tizm, vorozhbitstvo i kul'turni upodobannia [Sacred and Secular. Myths, Dreams and Mysteries. Mephistopheles and Androgynes. Occult, Divination and Cultural Tastes] / M. Yeliade. - K. : Vid-vo Solomi Pavlichko "Osnovi", 2001. - 591 s.

\section{Мельничук М. С. Экзегеза фантазии в ракурсе истоков религиозного искусства.}

Автор статьи исследует место и роль фантазии в процессе возникновения и функционирования религиозного искусства. В данном научном исследовании поддаются демаркации понятия религиозной и художественной фантазии. Анализируется данное явление и как результат образного обобщенного мышления и как внутренняя духовная необходимость осознания ирраџионального. Фантазия, автором представлена как непременный элемент религиозного искусства, который отражает формы существования, познания и деятельности человека.

Ключевые слова: фантазия, религия, искусство, религиозное искусство, эмочии, катарсис.

\section{Melnichuk M. S. Exegesis of Fantasy in the Perspective of the Origins of Religious Art.}

The author of the article explores the place and role of fantasy in the process of the emergence and functioning of religious art. In this scientific study amenable to the demarcation of the concept of religious and artistic fantasy. This phenomenon is analyzed both as a result of figurative generalized thinking and as an inner spiritual necessity of awareness of the irrational. Fantasy, the author is presented as an indispensable element of religious art, which reflects the forms of existence, knowledge and human activities. The spiritual situation against the background of the realities of modern Ukraine seems to be new trends in the consideration of such a phenomenon as religious art. A significant role in the process of the birth and development of religious art, and their interaction, was played by human fantasy. But her role was polyhedral character. From the side of aesthetic feelings, with all their strength and their diversity of interests directed at a real object, they acted as a specific "practical-spiritual" form of its assimilation. Religious feelings are always directed at illusory, nonexistent objects.

Religious fantasy populates virtual reality with supernatural beings, ascribes supernatural properties and connections to real objects and phenomena, endows its "offenses" with unlimited power over nature and man, and sees the world as the result of God's creation and as a sphere of the manifestation of divine will. And as a result, it is embodied in the eternal, divine masterpieces of world religious art, able to guide a person to the eternal, good, and bright.

Key words: fantasy, art, religion, religion art, emotion, catharsis. 